\title{
New records of Phascolosoma turnerae (Sipuncula: Phascolosomatidae) from the Balearic Basin, Mediterranean Sea
}

\author{
J.I. SAIZ ${ }^{1}$, J.E. CARTES ${ }^{2}$, V. MAMOURIDIS ${ }^{2}$, A. MECHO $^{2}$ AND M.A. PANCUCCI-PAPADOPOULOU ${ }^{3}$ \\ ${ }^{1}$ Department of Zoology and Cell Biology, UPV/EHU, PO Box 644, 48080 Bilbao, Spain, ${ }^{2}$ Institut de Ciències del Mar (CSIC), \\ Passeig Marítim de la Barceloneta 37-49, 08003 Barcelona, Spain, ${ }^{3}$ Hellenic Centre for Marine Research, PO Box 712, 19013 \\ Anavissos, Greece
}

Specimens of the deep-water sipunculan worm Phascolosoma (Phascolosoma) turnerae were recently collected from the western part of the Mediterranean Sea. This species is characterized by hooks showing a peculiar anterior stout and long projection at their base. A key to all the Phascolosoma species found in the Mediterranean Sea is included.

Keywords: Phascolosoma turnerae, new records, western Mediterranean, sipunculan worm

Submitted 6 August 2013; accepted 24 January 2014

\section{INTRDDUCTION}

The genus Phascolosoma Leuckart, 1828 , is one of the most species-rich genera within the phylum Sipuncula (Murina, 1984; Gibbs \& Cutler, 1987; Cutler, 1994), with the majority of its species showing a preference for the warmer shallow waters of the world's oceans (Murina, 1975). However, a few phascolosomatid species are rare in their geographical distribution (Cutler, 1994), since they show preferences for deep cold waters instead.

Deep-sea communities in the Mediterranean are poorly known (Bazairi et al., 2010). Recent studies conducted over the slope of the Balearic Basin (western Mediterranean) revealed the presence of deep-sea phascolosomatids (Cartes et al., 2009). They were identified as Phascolosoma turnerae Rice, 1985 in a taxonomic checklist of the sipunculan fauna for the Mediterranean Sea (Coll et al., 2010). The new phascolosomatids inhabited muddy bottoms in the Balearic Basin. From this area, a total of 7 other species of sipunculans have been collected (Cartes et al., 2009; Mamouridis et al., 2011; Tecchio et al., 2013) by using different bottom trawls and box-corers at depths between 427 and $2265 \mathrm{~m}$. This relatively high diversity of sipunculans was related to their ability in exploiting particulate organic matter of different quality (more or less degraded), arriving at bathyal depths, as inferred by the quite different stable isotope $\delta^{15} \mathrm{~N}$ found in Aspidosiphon muelleri Diesing, 1851 and Sipunculus norvegicus Danielssen, 1869 (respectively $5.39 \%$ and $9.57 \%$, Fanelli et al., 2011), two dominant sipunculan species inhabiting the investigated area (Cartes et al., 2009).

After a detailed anatomical study of the phascolosomatid specimens collected, we observed anatomical features unknown to any previously recorded Mediterranean species (Pancucci-Papadopoulou et al., 1999) of the genus

Corresponding author:

J.I. Saiz

Email: ji.saiz@ehu.es
Phascolosoma Leuckart, 1828. Thus, the aims of the present study are: (1) to report this new faunistic finding for the Mediterranean Sea; and (2) to select reliable characters for the distinction of closely related species. The ecological information of those collected specimens is also discussed.

\section{MATERIALS AND METHODS}

Specimens of deep-sea phascolosomatids were collected during trawling operations of the RV 'García del Cid' in the north-western part of the Mediterranean Sea. Station names, coordinates, depths, sampling dates and number of specimens are listed as follows:

-Station $\quad \mathrm{BIOM}_{3}-\mathrm{OTSB} 4 ; \quad 41^{\circ} 07.130^{\prime \prime}-41^{\circ} 07.841^{\prime \prime} \mathrm{N}$ $2^{\circ} 22.497^{\prime \prime}-2^{\circ} 27.977^{\prime \prime} \mathrm{E} ; 1039-1103 \mathrm{~m}$; 01/07/2007; 2 specimens. -Station $\mathrm{PROMETEO}_{3} \mathrm{M}-28 ; \quad 41^{\circ} 07^{\prime} 60^{\prime \prime} \mathrm{N} \quad 02^{\circ} 52^{\prime} 16^{\prime \prime} \mathrm{E}$; 1500 m; 13 May 2009; 1 specimen.

Immediately after sampling, all samples were preserved in $4 \%$ borax-buffered formaldehyde, prepared using seawater. Once in the laboratory, the material was studied using standard dissecting techniques and both binocular and compound microscopes. The species identification was based mainly on the works of Cutler (1994) and Pancucci-Papadopoulou et al. (1999). Voucher material was deposited at the Institut de Ciències del Mar (CSIC).

\section{RESULTS}

SYSTEMATICS

Phascolosoma (Phascolosoma) turnerae Rice, 1985 (Figure $1 \mathrm{~A}-\mathrm{F}$ )

Trunk 23-44 mm long and 9-12 mm wide, light brown in colour (Figure $1 \mathrm{~A}$ ). Skin opaque to translucent. Papillae 

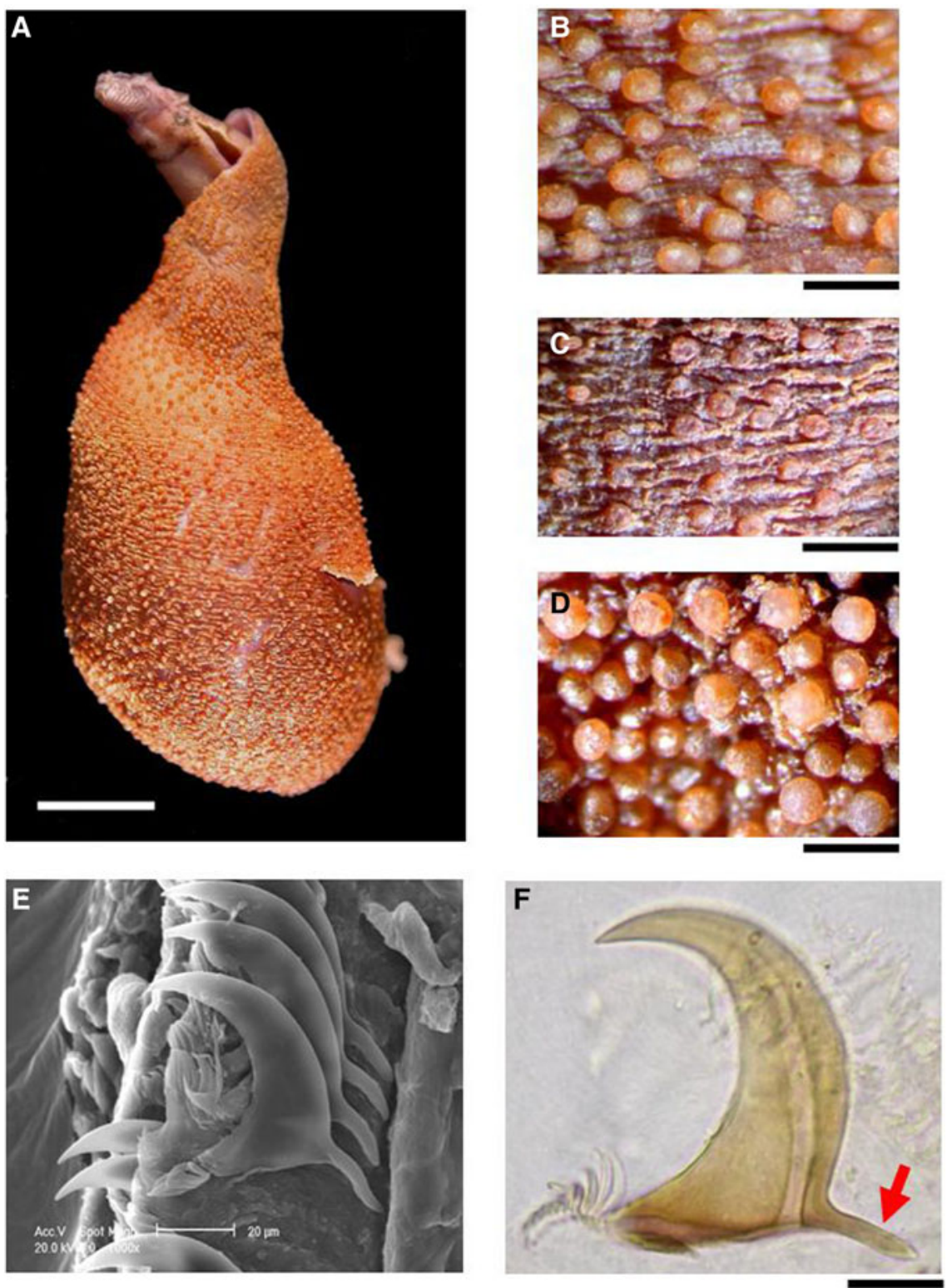

Fig. 1. Phascolosoma (Phascolosoma) turnerae: (A) external view; (B) papillae in the anterior part of the trunk; (C) papillae in the middle part of the trunk; (D) papillae at the trunk end; (E) scanning electron micrograph of a hook ring; (F) detail of a hook under the light microscope. Red arrow indicates the characteristic long basilateral extension of the hook. Scale bars: A, $5 \mathrm{~mm}$; B and D, $0.5 \mathrm{~mm} ; \mathrm{C}, 0.3 \mathrm{~mm} ; \mathrm{F}, 20 \mu \mathrm{m}$.

distributed over the entire trunk, larger and more densely packed at both ends (Figure $1 \mathrm{~B}, \mathrm{D}$ ). Introvert 25-42 $\mathrm{mm}$ long with some pigmented bands. About 28 digitiform tentacles unpigmented. About 90 hook rings, many incomplete. Under the microscope hooks appear slightly curved without a secondary tooth (Figure $1 \mathrm{E}$ ). Height $50-75 \mu \mathrm{m}$. At the posterior base of the hooks there are long toes and a basal wart. A long clear streak with some expansion is noted. No triangles, but with a characteristic long basilateral extension (Figure $1 \mathrm{~F}$ ). Tubuliform papillae about $10 \mu \mathrm{m}$ high are placed between the hook rings. Internally, the longitudinal musculature has about 30-34 anastomosing bands. Circular musculature also split in fine bands. Four retractors the ventral arising from $6-8$ bands, whereas the dorsal arise from 7-8 bands. The distance from the ventral insertions to the trunk end is $5-10 \mathrm{~mm}$. Gut organized in about 15 spirals. Spindle muscle present and attached posteriorly. Two nephridia, $11 \mathrm{~mm}$ long with the posterior
$2 \mathrm{~mm}$ free. Nephridiopores open a little anterior to the anus. Gonads observed at the base of the ventral retractors.

\section{DISCUSSION}

A total of 5 species of Phascolosoma have been reported from the Mediterranean Sea at coastal waters varying from o to $230 \mathrm{~m}$ deep (Pancucci-Papadopoulou et al., 1999). The collection of deep-water phascolosomatids in the mainland slope of the Balearic Basin was remarkable, since we were unable to relate them to any representative of the genus Phascolosoma for the Mediterranean Sea. According to Cutler (1994), the nature of the hooks appears to be species-specific within this sipunculan genus and a global key for the identification of all valid species was constructed by using basically the detailed study of the hooks under the light microscope. In this way, the 
presence of characteristic hooks with anterior prong-like extensions related our specimens to only the two species exhibiting this character: Phascolosoma turnerae Rice, 1985; and $P$. saprophagicum Gibbs, 1987. Gibbs (1987) differentiated the two species by: (i) the height of the hooks $(>45-80 \mu \mathrm{m}$ in $P$. turnerae vs $20-25 \mu \mathrm{m}$ in $P$. saprophagicum); and (ii) the external shape of the hooks (sharply-pointed in P. turnerae vs bluntly-rounded in $P$. saprophagicum). Since our specimens showed sharply bent hooks, $50-75 \mu \mathrm{m}$ tall, we have identified them with $P$. turnerae.

The faunistic finding is also interesting from an ecological approach. The species was described originally by Rice (1985) inhabiting submerged wood at bathyal depths in the Strait of Florida and the Gulf of Mexico. The large abundance of sipunculans boring the wood persuaded this author to note a biological association between this sipunculan species and the wood. Similarly, our BIOM3-OTSB4 specimens were collected (after 4.5 ha of trawling) together with a large piece $(\sim 25 \mathrm{~kg})$ of a tree trunk, some tree leaves (from purple beech, Fagus sylvatica) and Posidonia oceanica remains, suggesting this ground located near Besós Canyon could be a depocentre area for terrestrial-shelf material. These terrestrial inputs are patchily distributed over the slope (authors, unpublished data), although they are more frequent in the mainland than in the insular slope of the Balearic Basin, with higher levels of total organic matter at $1000-1100 \mathrm{~m}$ (Fanelli et al., 2013). $\delta^{13} \mathrm{C}$ stable isotope signals on sediments close to the $\mathrm{BIOM}_{3}-\mathrm{OTSB}_{4}$ haul (between $-23.6 \% /-24.8 \%$ Fanelli et al., 2013) also suggests an enrichment of terrigenous sediments there.

Almost simultaneously Edmonds (1985) described a new species, Phascolosoma kapalum, from deep bottoms off Australia. In this paper, there was no indication of wood occupation by the sipunculans. Later on, Edmonds (1992) compared specimens of $P$. kapalum with $P$. turnerae and decided that the two taxa were conspecific, the first name being a junior synonym of the last one. The finding of an extra specimen from a piece of rotting wood off the Great Barrier Reef (Australia) confirmed the character of a deep-sea wood dweller. However, in the review of the subgenus Phascolosoma achieved by Cutler \& Cutler (1990), they identified further specimens from bathyal depths in the Gulf of Mexico, but this time the association was noted with tubeworm aggregations near a cold water seep. Other more ecological papers (Olu et al., 1996, 2010; MacAvoy et al. 2005; Cordes et al., 2006, 2007) reported the species also in mussel beds and sediments at the base of the tubeworm aggregations from different cold seep sites around the Gulf of Mexico, but also offshore the Orinoco River delta in South America (at 1950-2080 m deep in sediment samples).

Another rare phascolosomatid, P. saprophagicum Gibbs, 1987, was collected from bathyal depths close to Chatham Island (New Zealand). Several specimens were obtained from the crevices and between the attached mussels on a large piece of decaying bone corresponding to a whale skull. Both $P$. saprophagicum and $P$. turnerae are the only representatives of the genus colonizing bizarre ephemeral habitats in deeper waters. Moreover, both species share this unique basal projection at the anterior base of the hook. Whereas we can suspect the existence of some genetic affinity between the two species, only DNA has been sequenced by now from $P$. turnerae (Kawauchi et al., 2012). Consequently, $P$. turnerae and $P$. saprophagicum, remain separate valid entities, as was proposed in the last monograph about the phylum (Cutler, 1994).
Recently, a comprehensive and detailed study on the reproductive biology and life-history of $P$. turnerae was published (Rice et al., 2012), since the authors were able to maintain several specimens in captivity for long periods of time. Interestingly, other kinds of habitats were reported for the species, such as authigenic carbonate rocks and bundles of plant fibres, which inspired the authors to design artificial collectors of deep-sea phascolosomatids. The species was additionally found in bathyal depths close to the Bahamas and Barbados, showing by now a disjunct geographical distribution of two remote areas: the western Atlantic and south-western Pacific Oceans. To explain this gap, Rice et al. (2012) suggested the possibility of a wider distribution than currently known for P. turnerae. This hypothesis is today more plausible, with the discovery of $P$. turnerae in bathyal depths of the Mediterranean Sea (Bienhold et al., 2013; our findings). In this way, these locations within the Mediterranean Sea represent an intermediate spot between the two remote areas where the species was previously collected. The presence of $P$. turnerae in the Mediterranean Sea has also implications in a potential connection of disjunct metapopulations of $P$. turnerae from both sides of the Atlantic Ocean. Dispersal trajectories of planktonic larvae were simulated in a recent study of this wood-dwelling species (Young et al., 2012). Its larvae were capable of reaching the mid-Atlantic off Newfoundland, a distance of more than $3000 \mathrm{~km}$, during a long drifting period. Consequently, the possibility of a genetic exchange from west to east in the North Atlantic Drift current is even more probable, specimens of $P$. turnerae having been collected in the Mediterranean Sea.

Finally, we were unable to note a direct association of $P$. turnerae with sunken wood in the western part of the Mediterranean Sea. However, Bienhold et al. (2013) did recently by deploying wood colonization experiments offshore the River Nile delta at a depth of $1690 \mathrm{~m}$ (eastern Mediterranean Sea). In our case, $P$. turnerae was the only sipunculan species collected in both hauls, while other sipunculans are relatively abundant from other sampling sites (Cartes et al., 2009; Mamouridis et al., 2011; Tecchio et al., 2013) over the investigated slope. In general, surface depositfeeder invertebrates were poorly represented in the first reported haul (only 1 holothurian, Mesothuria intestinalis), while the rest of invertebrates were-based on stable isotope analyses in the same area (Fanelli et al., 2011, in 2013)both filter feeders (1 bivalve Abra longicallus; 1 holothurian Ypsilothuria bitentaculata) and carnivores (1 seastar Ceramaster grenadensis). This suggests that inputs of fresh organic matter, as found deeper (e.g. over $1600 \mathrm{~m}$, Cartes et al., 2009), are low within the trawled area, indirectly reinforcing the idea that $P$. turnerae would have as food source ephemeral material derived from terrestrial inputs, such as remains of wood.

KEY TD THE GENUS

PHASCOLOSOMA LEUCKART

1828, FRDM THE MEDITERRANEAN SEA [MDDIFIED FROM PANCUCCIPAPADDPDULDUET AL. (1999) TD ACCDMMDDATE THENEW RECDRD]

1a. Hooks under the light microscope exhibiting an anterior stout and long projection at the base of their convex side ..................................................................... P. turnerae 
1b. Hooks without an anterior projection at the base of their convex side

2a. More than 50 complete and incomplete rings of hooks over the full everted introvert

2b. Less than 50 complete and incomplete rings of hooks ..4

3a. Hooks with a posterior crescent area, many $>75 \mu \mathrm{m}$ tall; preanal papillae are smooth cones; pigment bands on introvert ........................................................ P. stephensoni

3b. Hooks with a granular triangle at their anterior base, but without crescents, most $<75 \mu \mathrm{m}$ tall; no pigment bands on introvert ................................................. P. granulatum

4a. Large rounded hump on concave side of the hook; preanal papillae smooth, posteriorly directed, cone shaped ............................................................. P. perlucens

4b. Concave side of hook smooth or with small tooth ....... 5

5a. Hooks with distinct triangle; narrow band of red coneshaped preanal papillae ........................................ P. scolops

5b. Hook triangle indistinct or absent; preanal papillae not distinct from dome-shaped trunk papillae

P. agassizii agassizii.

\section{ACKNDWLEDGEMENTS}

This study was funded by the Spanish Ministry of Science projects ANTROMARE (J.E.C. and V.M. ref. CTM200912214-Co2-01/MAR) and PROMETEO (A.M. ref. CTM200766316-Co2/MAR). The authors thank all the participants of both scientific cruises. Special thanks to Dr Th. Kanellopoulos for scanning electronic microscope shooting at the HCMR premises in Anavyssos.

\section{REFERENCES}

Bazairi H., Ben Haj S., Boero F., Cebrian D., De Juan S., Limam A., Lleonart J., Torchia G. and Rais C. (2010) The Mediterranean Sea biodiversity: state of the ecosystems, pressures, impacts and future priorities. Tunis: UNEP-MAP RAC/SPA, $100 \mathrm{pp}$.

Bienhold C., Pop Ristova P., Wenzhöfer F., Dittmar T. and Boetius A. (2013) How deep-sea wood falls sustain chemosynthetic life. PLoS ONE 8, e53590. doi:10.1371/journal.pone.0053590.

Cartes J., Maynou F., Fanelli E., Romano C., Mamouridis V. and Papiol V. (2009) The distribution of megabenthic, invertebrate epifauna in the Balearic Basin (western Mediterranean) between 400 and $2300 \mathrm{~m}$ : environmental gradients influencing assemblages composition and biomass trends. Journal of Sea Research 61, 244-257.

Coll M., Piroddi C., Steenbeek J., Kaschner K., Lasram F.B.R., Aguzzi J., Ballesteros E., Bianchi C.N., Corbera J., Dailianis T., Danovaro R., Estrada M., Froglia C., Galil B.S., Gasol J.M., Gertwagen R., Gil J., Guilhaumon F., Kesner-Reyes K., Kitsos M.-S., Koukouras A., Lampadariou N., Laxamana E., Lotze H.K., Martin D., Mouillot D., Oro D., Raicevich S., Rius-Barile J., Saiz-Salinas J.I., San Vicente C., Somot S., Templado J., Turon X., Vafidis D., Villanueva R. and Voultsiadou E. (2010) The biodiversity of the Mediterranean Sea: estimates, patterns, and threats. PLOS ONE 5, e11842. doi:10.1371/journal.pone.0011842.

Cordes E.E., Bergquist D.C., Predmore B.L., Jones C., Deines P., Telesnicki G. and Fisher C.R. (2006) Alternate unstable states: convergent paths of succession in hydrocarbon-seep tubeworm-associated communities. Journal of Experimental Marine Biology and Ecology $339,159-176$.

Cordes E.E., Carney S.L., Hourdez S., Carney R.S., Brooks J.M. and Fisher C.R. (2007) Cold seeps of the deep Gulf of Mexico: community structure and biogeographic comparisons to Atlantic equatorial belt seep communities. Deep-Sea Research I 54, 637-653.

Cutler N.J. and Cutler E.B. (1990) A revision of the subgenus Phascolosoma (Sipuncula: Phascolosoma). Proceedings of the Biological Society of Washington 103, 691-730.

Cutler E.B. (1994) The Sipuncula: their systematics, biology, and evolution. Ithaca, NY: Cornell University Press, 453 pp.

Edmonds S.J. (1985) A new species of Phascolosoma (Sipuncula) from Australia. Transactions of the Royal Society of South Australia 109, 43-44.

Edmonds S.J. (1992) A note on Phascolosoma turnerae (Sipuncula). Transactions of the Royal Society of South Australia 116, 151.

Fanelli E., Papiol V., Cartes J.E., Rumolo P., Brunet C. and Sprovieri M. (2011) Food web structure of the megabenthic, invertebrate epifauna on the Catalan slope (NW Mediterranean): evidence from $\delta^{13} \mathrm{C}$ and $\delta^{15} \mathrm{~N}$ analysis. Deep-Sea Research I 58, 98-109.

Fanelli E., Papiol V., Cartes J.E., Rumolo P. and López-Pérez C. (2013) Trophic webs of deep-sea megafauna on mainland and insular slopes of the NW Mediterranean: a comparison by stable isotope analysis. Marine Ecology Progress Series 490, 199-221.

Gibbs P.E. (1987) A new species of Phascolosoma (Sipuncula) associated with a decaying whale's skull trawled at $880 \mathrm{~m}$ depth in the south-west Pacific. New Zealand Journal of Zoology 14, 135-137.

Gibbs P.E. and Cutler E.B. (1987) A classification of the phylum Sipuncula. Bulletin of the British Museum of Natural History, Zoology 52, 43-58.

Kawauchi G.Y., Sharma P.P. and Giribet G. (2012) Sipunculan phylogeny based on six genes, with a new classification and the descriptions of two new families. Zoologica Scripta 41, 186-210.

MacAvoy S.E., Fisher C.R., Carney R.S. and Macko S.A. (2005) Nutritional associations among fauna at hydrocarbon seep communities in the Gulf of Mexico. Marine Ecology Progress Series 292, 51-60.

Mamouridis V., Cartes J.E., Parra S., Fanelli E. and Saiz Salinas J.I. (2011) A first temporal analysis on the dynamics of deep-sea macrofauna: influence of environmental variability off Catalonia coasts (western Mediterranean). Deep-Sea Research I 58, 323-337.

Murina V.V. (1975) The geographical distribution of marine worms of the phylum Sipuncula of the World Ocean. In Rice M.E. and Todorović M. (eds) Proceedings of the International Symposium on the Biology of Sipuncula and Echiura Volume 1. Belgrade, Serbia: Naučno Delo, pp. 3-18.

Murina G.-V.V. (1984) Ecology of Sipuncula. Marine Ecology Progress Series $17,1-7$.

Olu K., Sibuet M., Harmegnies F., Foucher J.-P. and Fiala-Medioni A. (1996) Spatial distribution of diverse cold seep communities living on various diapiric structures of the southern Barbados prism. Progress in Oceanography 38, 347-376.

Olu K., Cordes E.E., Fisher C.R., Brooks J.M., Sibuet M. and Desbruyères D. (2010) Biogeography and potential exchanges among the Atlantic Equatorial Belt cold-seep faunas. PLoS ONE 5, e11967. doi: 10.1371/journal.pone.0011967.

Pancucci-Papadopoulou M.A., Murina G.V.V. and Zenetos A. (1999) The phylum Sipuncula in the Mediterranean Sea. Monographs on Marine Sciences. Athens: National Center for Marine Research, 109 pp.

Rice M.E. (1985) Description of a wood dwelling sipunculan, Phascolosoma turnerae, new species. Proceedings of the Biological Society of Washington 98, 54-60.

Rice M.E., Reichardt H.G., Piraino J. and Young C.M. (2012) Reproduction, development, growth, and the length of larval life of Phascolosoma turnerae, a wood-dwelling deep-sea sipunculan. Invertebrate Biology 131, 204-215. 
Tecchio S., Ramírez-Llodra E., Aguzzi J., Sanchez-Vidal A., Flexas M., Sardà F. and Company J.B. (2013) Seasonal fluctuations of deep megabenthos: finding evidence of standing stock accumulation in a flux-rich continental slope. Progress in Oceanography 118, 188-198.

and

Young C.M., He R., Emlet R.B., Li Y., Qian H., Arellano S.M., Van Gaest A., Bennett K.C., Wolf M., Smart T.I. and Rice M.E. (2012) Dispersal of deep-sea larvae from the Intra-American Seas: simulations of trajectories using ocean models. Integrative and Comparative Biology 52, 483-496.

\section{Correspondence should be addressed to:}

J.I. Saiz

Department of Zoology and Cell Biology University of the Basque Country/EHU PO Box 644, 4808o Bilbao, Spain email: ji.saiz@ehu.es 